\title{
Prevalence of Laryngeal Alterations in Patients with Erosive Esophagitis
}

\section{Prevalência de Alterações Laríngeas em Portadores de Esofagite Erosiva}

\author{
Marina Serrato Coelbo*, Evaldo Macedo**, Marcos Mocellin ${ }^{* * *, \text { Ricardo Guzela }}{ }^{* * *}$ \\ Odery $\operatorname{Ramos} \boldsymbol{J} \boldsymbol{r} * * * *$.
}

\author{
* Resident in Otorhinolaryngology, HC-UFPR \\ ** Doctor. Professor of Otolaryngology Department of the HC-UFPR. \\ **** Doctor. Head of the Department of Otorhinolaryngology, HC-UFPR. \\ ***** Physician. Resident in the Department of Gastroenterology, HC-UFPR. \\ ****** Master. Professor in the Department of Gastroenterology, HC-UFPR. \\ Institution: Hospital of UFPR \\ Curitiba / PR - Brazil. \\ Mail Address: Marina Serrato Coelho - Rua Francisco Juglair, B 298301 - Curitiba / PR - Brazil - Zip code: 81200-230 - Telephone: (+55 41) 3360-1800 - E-mail: \\ ma.serrato@hotmail.com \\ Article received in January 27, 2010. Article accepted in April 21, 2010.
}

\section{SUMMARY}

Introduction:

The association between gastroesophageal reflux disease (GERD) and laryngeal disorders has been much debated in recent years. Recent studies suggest an association between laryngeal symptoms and pharyngeal symptoms extra-esophageal reflux, as atypical presentation of Gastroesophageal Reflux Disease.

Objectives:

To correlate the presence of laryngeal to the grades of erosive esophagitis.

Methods:

A prospective study. Patients with findings of esophagitis on endoscopy were categorized according to LosAngeles and submitted a questionnaire followed by laryngoscopy. The chi-square test was used for statistical analysis $(p<0.05)$.

Results:

Patients with typical symptoms of gastroesophageal reflux disease accounted for $96.6 \%$. Eighteen had changes consistent with class A (60\%), class B with seven (7\%) and 5 with classes C + D (16.6\%). The presence of laryngeal changes were more prevalent in more severe esophagitis (grades C and D Los Angeles) when compared to milder forms (classes A and B), a statistically significant difference $(p<0.05)$.

Conclusion: The laryngeal disorders are frequent findings in patients with esophagitis, more frequent the greater the degree of esophageal injury.

Keywords: esophagitis, gastroesophageal reflux, laryngitis.

\section{RESUMO}

Introdução:

A associação entre Doença do Refluxo Gastroesofágico (DRGE) e alterações laríngeas vem sendo muito debatida nos últimos anos. Estudos recentes sugerem associação entre sintomas laríngeos, sintomas faríngeos e refluxo extra-esofágico, como sendo apresentação atípica da Doença do Refluxo Gastroesofágico.

Objetivo:

Método:

Correlacionar a presença de alterações laríngeas com os graus de esofagite erosiva.

Estudo prospectivo. Os pacientes com achados de esofagite a endoscopia foram classificados de acordo com Los Angeles e submetidos a um questionário seguido de laringoscopia. O teste do quiquadrado foi utilizado para análise estatística $(\mathrm{p}<0,05)$.

Resultados: Os pacientes com sintomas típicos de refluxo gastroesofágico corresponderam a 96,6\%. Dezoito possuíam alterações compatíveis com classe A(60\%), 7 com classe B (7\%) e 5 com classes C + D (16,6\%). A presença de alterações laringoscópicas foi mais prevalente nas esofagites mais severas (classes C e D de Los Angeles) quando comparada aos graus mais leves (classes A e B), diferença estatisticamente significativa $(p<0,05)$

Conclusão: As alterações laríngeas são achados frequentes nos pacientes com esofagite, sendo mais prevalentes quanto maior o grau da lesão esofágica.

Palavras-chave: esofagite, refluxo gastroesofágico, laringite. 


\section{INTRODUCTION}

Erosive esophagitis - esophageal mucosal injury caused by both agents extrinsic as intrinsic agents - change is routinely found in diagnostic centers in gastroenterology, very often related to Gastroesophageal Reflux Disease (GERD). GERD it is, the high prevalence of a public health problem, a chronic disease, recurrent and impairing daily activities (1)

The association between GERD and laryngeal disorders has been discussed since 1960 (2). Recent studies suggest an association between laryngeal symptoms and pharyngeal symptoms extra-esophageal reflux, as atypical presentation of Gastroesophageal Reflux Disease (3).

The ENT symptoms can be classified into one entity called laryngopharyngeal reflux (LPR), defined as being the result of retrograde gastric contents into the light larynx, when, it comes in contact with the upper aerodigestive tract (4). Most patients with LPR do not present classic symptoms of GERD such as heartburn and regurgitation (5). It is postulated that approximately 50$60 \%$ of chronic laryngitis are unwieldy compared with GERD (2).

Are nonexistent in the literature that relates the degree of esophagitis with the presence and degree of laryngeal lesions. This question appears to be important, since it modifies the proposed treatment, and improved significantly and more quickly and effectively the quality of life of patients correctly treated, according to the extent of their disease.

The aim of this study is to determine the prevalence of laryngeal disorders in patients with erosive esophagitis, evaluated in Digestive Endoscopy Service, Hospital de Clinicas, Federal University of Parana - HC / UFPR. And our specific objective is to correlate the presence of changes in laryngeal comparison with the degree of erosive esophagitis.

\section{METHOD}

Cross-sectional prevalence study conducted in the Departments of Digestive Endoscopy and Per-Oral Endoscopy, Hospital de Clínicas / UFPR.

We evaluated all patients undergoing upper endoscopy at the Endoscopy Service of HC / UFPR, elective, during the period February 2009 to September 2009. Patients with erosive esophagitis were classified

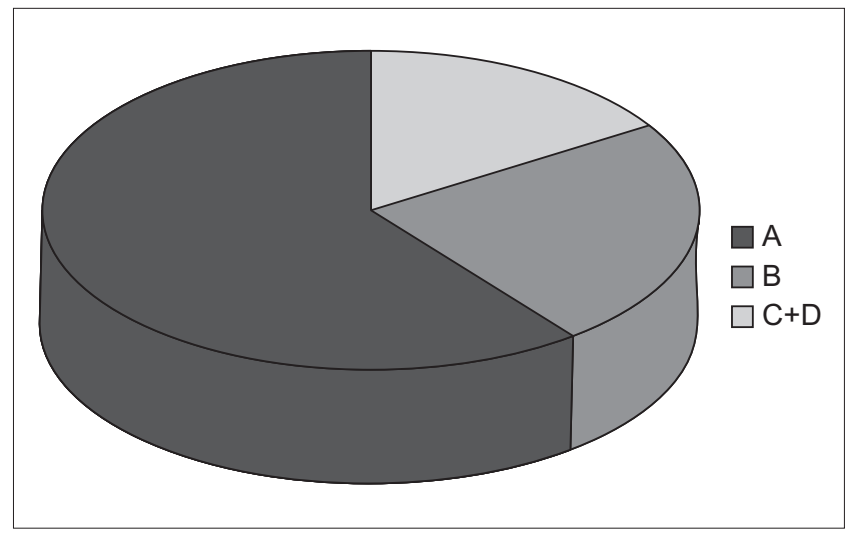

Graphic 1. Los Angeles classification for oesophagitis - A class B - class b; C + D - class $c+d$.

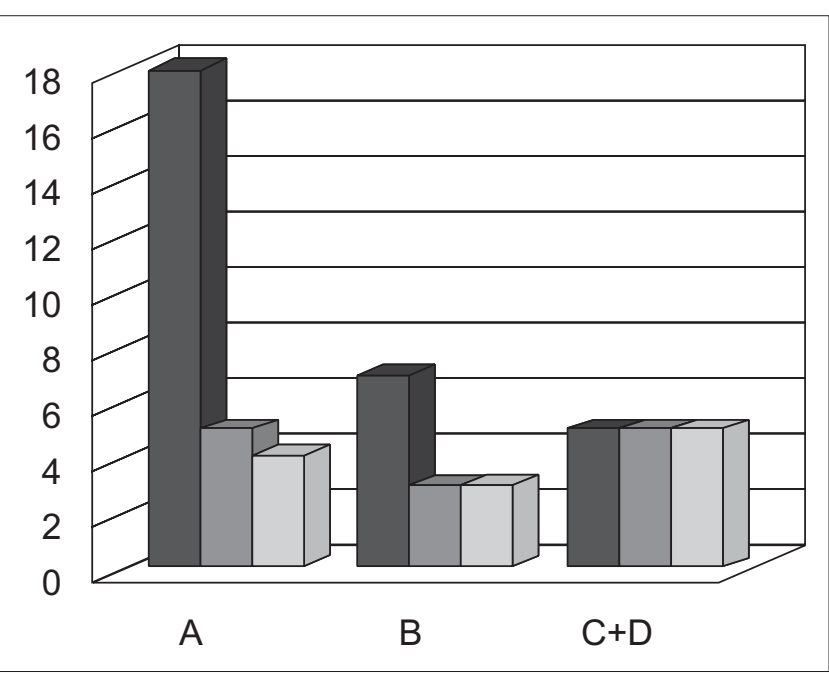

Graphic 2. Relation between changes in endoscopy, laryngoscopy and symptomatology in separate groups according to classification of Los Angeles - A - endoscopy; B - laryngoscopy; - C+D symptoms.

according to the criteria of Los Angeles (Graphic 1) and responded to the questionnaire (Graphic 2). Then they underwent direct laryngoscopy by the same examiner, using a rigid laryngoscope, and evaluated the presence of laryngeal disorders, as well as the nature of these lesions (redness, nodules on vocal cords, edema, signs of posterior laryngitis) and the degree of severity of these changes.

Data were organized into a database created in EpiInfo 6.0. Statistical analysis was performed in the "SPSS for Windows." The chi-square test was used to assess the relationship between the study variables. The significance level adopted was less than $5 \%(\mathrm{p}<0.05)$.

The protocol followed the MS conditions laid down in Resolution 196/96 of the National Health Council (CNS). 
After the patients were informed of the purpose of the study all gave their written consent to participate. The study was approved by the Ethics Committee on Human Research, HC / UFPR (0292.0.208.000-08).

\section{RESULTS}

Thirty patients completed the study. Of these, 16 were male (53.3\%) and 14 females (46.6\%). The mean age was 49.1 years, ranging between 27 and 81 years.

Patients with typical symptoms of gastroesophageal reflux disease accounted for $96.6 \%$, among these, $36.6 \%$ had atypical symptoms.

Patients were classified according to endoscopic findings according to the classification of Los Angeles. Eighteen had changes consistent with class A (60\%), class $\mathrm{B}$ with seven (7\%) and 5 with classes C + D (16.6\%).

Of the 18 patients who had endoscopic changes compatible with Class A of Los Angeles (60\%) of 73\% (13) had normal laryngoscopy and $27.7 \%$ (05) had changes consistent with posterior laryngitis. Only $22 \%$ (4) of the patients had atypical symptoms - of these, 50\% with changes laryngoscopy.

Among the 07 patients classified as class B from Los Angeles (23.3\%), 42.8\% (3) showed posterior laryngitis. Three complained of atypical symptoms (42.8\%), of which two showed abnormal laryngoscopy.

Class $\mathrm{C}$ and $\mathrm{D}$ were diagnosed in 5 patients (16.6\%) all showed abnormal laryngoscopy: 3 posterior laryngitis, a crack and a triangular posterior varicosity. All patients were symptomatic.

The presence of laryngeal changes were more prevalent in more severe esophagitis (grades C and D Los Angeles) when compared to milder forms (classes A and B), a statistically significant difference $(\mathrm{p}<0.05)$.

\section{DISCUSSION}

According to the American Bronchoesophagological Association, the most common symptoms of LPR are hoarseness (97\%), globuspharyngeus (95\%) and hoarseness (95\%) (9).

KOUFMAN (10) was the first to distinguish GERD LPR, in his study with 899 patients found that hoarseness was found in $87 \%$ of patients with LPR and only $3 \%$ of patients with GERD, heartburn was already present in $83 \%$ of patients with GERD, whereas only $20 \%$ occurred in patients with LPR.

There are three ways to confirm LPR: (1) improvement of symptoms after medical treatment with lifestyle changes and medication, (2) endoscopic observation of the mucosa affected(3) demonstration of reflux events in studies of $\mathrm{pH}$ monitoring and study impedance multichannel (4).

VAEZ (11) states that the EDA has a positivity of only $50 \%$ of endoscopic esophageal injury in patients with typical symptoms of GERD in patients with LPR has that number reaches only 20\%. Due to low sensitivity of EGD and $\mathrm{pH}$ monitoring, and low specificity of laryngoscopy, empiric treatment with PPI has been considered the first step in the diagnosis of extra-esophageal manifestations of GERD (2). Those patients in which there is no response other diagnosis should be investigated.

Endoscopic findings generally show nonspecific signs, however, suggestive of LPR: hyperemia, edema and narrowing mainly concentrated in the posterior larynx (posterior laryngitis).The endoscopic examination (either rigid or flexible laryngoscope) should be performed in all patients suspected of LPR (12). In a study published by YLITALO (12), 74\% of laryngeal contact granulomas were related to LPR. The pseudosulco was found 2.5 times more often in patients with LPR (13). However, only $70 \%$ of pseudosulcos are related to LPR.

Laryngeal inflamed tissues are more easily damaged during intubation, the greatest risk of granulomas and contact ulcers, and often are involved in symptomatic subglottic stenosis and lower airway disease (4).

Benini et al (14), studying the effect of mucosal damage as much as esophageal larynx as a cause of decreased cough threshold, the study included only patients with esophagitis, a total of 21 patients, found an incidence of posterior laryngitis in 13 patients (61.9\%).

In a study by Toros et al (5), only $11 \%$ of patients with LPR symptoms showed changes consistent with GERD and endoscopy.

As occurs with GERD, the response to the treatment of laryngopharyngeal reflux (LPR) with proton pump inhibitors (PPIs) has been described as highly variable (15). Unlike GERD, treatment for LPR, in many cases, is more aggressive and prolonged in order to achieve full resolution (10).

The treatment of patients with LPR is based on the use of proton pump inhibitors in double dose, divided in 
two doses, 30-60 minutes before meals (4). If after three months of treatment with appropriate changes in lifestyle and appropriate doses of PPIs there is no response, no need for additional tests to confirm diagnosis.

When the doctor fails to recognize LPR, patients may have prolonged symptoms and delayed healing of injuries, as well as being subjected to unnecessary costs, often high by inadequate diagnosis (16).

\section{CONCLUSION}

Laryngeal disorders are frequent findings in patients with esophagitis, more frequent the greater the degree of esophageal injury. The doctor should therefore use both tests in their diagnostic armamentarium for patients with complaints of typical and atypical GERD.

\section{BibliograpHICAL REFERENCES}

1. Kenneth RV, Donald OC. Practice Guidelines: Update Guidelines for the Diagnosis and Treatment of Gastroesophageal Reflux Didease. American Journal of Gastroenterology. 2005, 100:190-200.

2. Farrokhi F, Vaezi MF. Extra-esophageal manifestions of gastroesophageal reflux. Oral Diseases. 2001, 13:34959 .

3. Ulualp SO, Toohill RJ, Shaker R. Outcomes of acid supressive therapy in patients with posterior laryngitis. Otolaryngol Head Neck Surg. 2001, 124:16-22.

4. Ford CN. Evaluation and Management of Laryngopharyngeal Reflux. Jama. 2005, 294(12):15341540.

5. Toros et al. Association of laryngopharyngeal manifestions and gastroesophageal reflux. Eur Arch Otorhinolaryngol. 2009, 266:403-9.

6. Barbuti RC, Moraes-Filho JPP. Doença do Refluxo Gastroesofágico. Gastroenterologia Medsi. 2004, 119-128.
7. Dent J. et al. An evid.ence-based appraisal of reflux disease management - the Genval Workshop Report. GUT. 1999, 44(2):S1-S16.

8. Pribuisene R, Uloza V, Jonaitis L. Typical and atypical symptoms of laryngopharyngeal reflux disease. Medicina. 2002, 38(7):699-705.

9. Book DT, et al. Perspectives in laryngopharyngeal reflux: an international survey. Laryngoscope. 2002, 16:274-277.

10. Koufman JA. The otolaryngologic manifestations of gastroesophageal reflux disease (GERD): a clinical investigation of 225 patients using ambulatory 24-hour $\mathrm{pH}$ monitoring and an experimental investigation of the role of acid and pepsin in the development os laryngeal injury. Laryngoscope. 1991, 101:01-78.

11. Vaezi MF. Laryngitis and gastroesophageal reflux disease: increasing prevalence or poor diagnostic tests? Am J Gastroenterol. 2004, 99:1000-1010.

12. Ylitalo R, Lindestad P, Ramel S. Symptoms, laryngeal findings, and 24-hour $\mathrm{pH}$ monitoring in patients with suspected gastroesophago-pharyngeal reflux. Laryngoscope. 2001, 111:1735-1741.

13. Belafky PC, Postma GN, Koufamn JA. The association between laryngeal pseudosulcus and laryngopharyngeal reflux.Otolaryngol Head Neck Surg. 2002, 126:649-52.

14. Benini L, et al. Cough threshold in reflux oesophagitis: influence of acid and of laryngeal and esophageal damage. GUT. 2000, 46:762-767.

15. Park W, et al. Laryngopharyngeal reflux: prospective cohort study evaluating optimal dose of proton-pump inhibitor therapy and pretherapy predictors of response. Laryngoscope. 2005, 115:1230-1238.

16. Ford CN. Advances and refinements in phonosurgery. Laryngoscope. 1999, 109(12):1891-1900.

17. Koufman J. Laryngopharyngeal reflux: consensus conference report. J Voice. 1996, 10:215-216. 